\title{
The role of technology in the economic growth of South Africa: The case of frequency allocations to cellular operators
}

\author{
A MELLET*
}

\begin{abstract}
Economists associate long-term economic growth with technological progress. Earlier growth literature, as well as modern literature, states to sustain a positive growth rate of output per capita in the long run, there must be continual advances in technological knowledge. This fact is embedded in one of the main growth models, namely the Solow growth model. This article firstly discusses the connection between technology and growth in the various models. Any country needs a positive real growth to develop. To create a better scenario for all its inhabitants, it is therefore important that technological development must be employed in the system. Secondly the focus is on analyzing the role of technology and mobile phones from a growth perspective in developing countries. Various studies by independent annalists are referred to regarding studies about the impact of mobile phones in Africa. Various African countries experienced development by using more mobile phones. Finally, attention is given to frequency allocation to provide voice or data access services for mobile phone users by ICASA, as the controlling body in South Africa. This scarce resource is not effectively allocated for the following reasons:

- the allocation between government institutions and private sector companies is not economically equitable; and

- the allocation amongst private sector companies is also not economically equitable. Ineffective frequency allocation is then considered to be a waste of a scarce resource. This wastage, against the background of studies in Africa regarding mobile phones and GDP, will accordingly reduce the potential development of all the inhabitants of South Africa.
\end{abstract}

\section{Keywords}

Economics, cellular technology, frequency allocations, production factors, growth theories, technology and growth, mobile phones, developing countries, Africa, competitiveness, AsgiSA,

* André Mellet is a lecturer in economics at the School of Economic Sciences, Vaal Triangle Campus of North-West University. He was Media24's economist of the year for 2006 .

TD: The Journal for Transdisciplinary Research in Southern Africa, Vol. 3 no. 2, December 2007, pp. 351-394 


\section{Disciplines}

Economics, Communications Studies, Information Technology Studies, Cellular Technology Studies.

\section{Introduction}

Economists associate long-term economic growth with technological progress because it is embedded in one of the main growth models, namely the Solow growth model (Solow, 1956). Technological change is treated as exogenous in this model, but technology is also treated as endogenous in other growth models. In earlier growth literature, technology is treated as the process that somehow made productivity to grow a little each year (Smith, 1904).

The modern literature views technology as being produced within the economic system by the rational and purposeful application of research and development as well as the growth of complementary human and physical capital.One of the opening lines of a standard textbook regarding growth states that the most basic proposition of growth theory is that in order to sustain a positive growth rate of output per capita in the long run, there must be continual advances in technological knowledge (Aghion and Howitt, 1997:11).

This survey discusses the connection between technology and growth. Any country needs a positive real growth to develop and to create a better scenario for all its inhabitants. The economic principles, for example scarcity and opportunity cost will be briefly analyzed. The different growth theories that explain why and how a country can increase its real growth rate will be analyzed and compared. The important links between technology and growth in this process will be highlighted.

The next step of this survey is to analyze the role of technology and mobile phones from a growth perspective in developing countries. The survey concludes with an analysis of frequency allocations in South Africa that can be used to provide voice or data access services.The current ineffective frequency allocation is a waste of a scarce resource and will accordingly reduce the potential real growth rate of South Africa.

\section{What is economics all about?}

According to (Smit et al, 1997:5) economics is the social science studying the principles of the effective employment of limited means with several alternative uses to satisfy multiple needs. According to (Mohr et al, 2004:5) economics is about scarcity and the management 
of limited sources relative to unlimited needs and the ongoing choices, which must be made.

The available means in economics are limited because natural resources such as gold, diamonds and oil are not available in unlimited quantities. Capital is another example, because capital is available but at a price and must be affordable. Frequency allocation as far as technology is concerned, is another example. If it is allocated and used, this scarce available means cannot be exploited by other users and their use of this means is restricted.

In society, unlimited needs exist. Needs are the extent in which people satisfy all their different wants, for example clothing, transport, housing, holidays and pension provision. Needs in business are the extent in which management satisfy their strategic plan objectives, for example to make a profit, to expand, to create work and to participate in the increase of living standards in society (obedient to their social responsibility).

Economics is thus the management of scarcity. The word economics is derived from the Greek words oikos, which means house and nemein which means management (Mohr et al, 2004:4). This management of the household regarding scarcity is applicable for the household of consumers, business and government. Consumers must make choices regarding buying groceries and going to the movies, business must make choices regarding profits to pay dividends or to finance expansion. The Minister of Finance, as another example, must make a choice between building a hospital and increasing grants to the poor.

Choices in economics imply opportunity costs. It means that when choices are made between different production techniques in business, the cost regarding the choice of one alternative can be measured in terms of the alternative which is sacrificed. Every time a choice is made, opportunity cost is raised. Opportunity cost is the value or cost of the alternative, which the decision maker could choose, but which he or she did not decide to apply. This concept of opportunity cost is one of the most important concepts in economics, because choices are made on a regular basis by consumers and business regarding scarce resources of which some resources continually decline.

The concept of opportunity cost can be found in the works of many early economists for example J.S. Mill, 1848 and L. Walras, 1874. The biggest contribution regarding the opportunity cost theory was introduced as a theory of cost in a seminar paper by Friedrich von Wieser (1876). In summary of these economists' contributions, output prices must equal opportunity costs. Thus, it seems as if prices are governed by the phenomena of opportunity cost.

TD, 3(2), December 2007, pp. 351-394 
A more careful look however indicates that it is demand, with its influence on output prices that determines which opportunity costs prevails. Prices and outputs are according to this theory subjectively determined. Opportunity cost theory is, according to Von Wieser, an objective theory of value, which is subjective. He explains:

\footnotetext{
The phenomena of [alternative] costs are, therefore, a new proof of how greatly the objective conditions of the existence of goods influence the value of goods. How far the value of goods, in its final form of "cost value", is from being the mirror of that subjective fact from which it is derived the value of wants! The circumstance that cognate products are produced by different quantities of the same productive elements, brings their subjective valuations into a ratio, the terms of which are derived entirely from the objective conditions of production; while the impulses which call for their emergence...remain subjective, and thus prove the subjectivity of the source and nature of value (Von Wieser, 1889:185).
}

In the graphical scenario a typical production possibility curve is illustrated. In this example, it is assumed the company is producing at point $\mathrm{I}$, which means that quantity $\mathrm{OC}$ is produced of product $\mathrm{X}$ and quantity $\mathrm{OE}$ is produced of product $\mathrm{Y}$. If management decides to produce at point $\mathrm{K}$, it means that they want to produce more of product $\mathrm{Y}$ and therefore the quantity $\mathrm{OG}$ of product $\mathrm{Y}$ or in other words an increase in production from $\mathrm{OE}$ to $\mathrm{OG}$. To be able to produce more of product $\mathrm{Y}$, they have to produce less of product $\mathrm{X}$ with their available resources. The decline in production from $\mathrm{OC}$ to $\mathrm{OA}$, therefore the quantity $\mathrm{AC}$ is what is sacrificed and thus the opportunity cost of producing more of product Y. 


\section{Figure1. A production possibility frontier}

Source: Smit et al (1997:396)

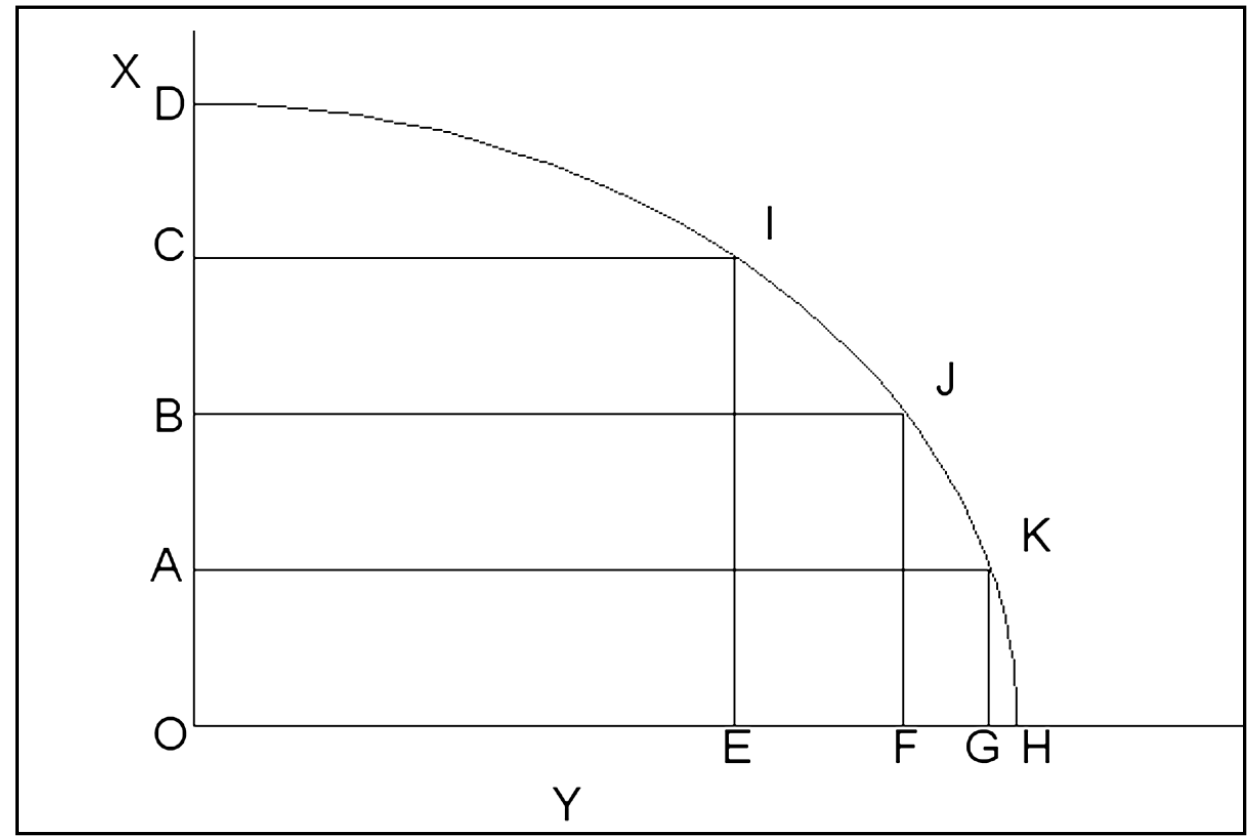

When choices are made, opportunity cost is incurred. If more is produced of one product relative to another product or if more technology is used by one market player relative to another market player, opportunity cost is incurred. The question is quite clear. If a choice is made by any management regarding scarce resources, is the cost of the sacrifice lower or higher? If the sacrifice is lower, it is a good choice of scarce resources, but if the cost is higher, it is an inefficient choice of scare resources.

\section{Production factors in economics}

According to (Mohr, 2004:27) there are five production factors:

\section{- Natural resources}

Natural resources are all the gifts of nature, for example minerals, water, land and air. These gifts however decline as consumers and business and government exploit it and pollute it. This factor of 
production is scarce, because if a mineral is mined, it is used in industry and the available quantity of the mineral in the mine declined accordingly.

\section{- Labour}

Labour can be the physical and or mental effort of the human being in the production process. A distinction is made between the quality and quantity of labour because skills are necessary in various production processes. Labour as production factor is scarce, because qualified workers must be trained on the job or at a tertiary institution, which cost money.

\section{- Capital}

Capital in economics is all the tools, machinery, equipment and buildings that are used to produce. It is thus all tangibles that are used to produce. The reason why it is scarce is that it is available only at a cost, namely the interest of the bank facility or the dividends not paid out but used to facilitate company growth.

\section{- Entrepreneurship}

It does not help if there are labourers, capital and resources available, but no one to manage the production process. An entrepreneur is the person that takes the initiative and the risk to use the other production factors to make a profit. If he or she is successful, the business will grow and more people will be employed which creates a positive multiplier effect in economics. The reason why this factor is scarce, is because an entrepreneur must have the flair and guts and training to enter into the risk scenario. Life experience tells us that there are many workers, but there are not many opportunists willing to take risk.

\section{- Technology}

Knowledge is important to produce products and services. At any given time, a certain quantity of knowledge is known and used by society. If new knowledge is discovered, it is referred to as an invention. If this invention is used in the production process, it is known as innovation. The production factors capital and entrepreneurship are used in combination in this process because people invent the new machines or techniques and capital is necessary to employ it in the production processes. If technology is employed in the production processes, products can either be produced faster or at a better quality or at a cheaper unit price. 
Although technology was added later as a production factor, it is generally accepted as a necessity in the growth processes of any country.

It is clear from the discussion above that various production factors are necessary to create growth. Economics is about the management of scarce resources and all of these five production factors must be employed in coordination with each other by any enterprise to gain the most.

\section{Growth theories}

\subsection{Classical growth theories}

Adam Smith wrote his famous book, namely An Inquiry into Nature and Causes of the Wealth of Nations in 1776. Smith moved away from the Physiocratic system which concentrated on natural equilibrium of circular flows. Smith described a supply-side model of growth. Growth via the simple production function (Smith, 1904) can be written as follows:

$\mathrm{Y}=\mathrm{f}(\mathrm{L}, \mathrm{K}, \mathrm{T})$

where $\mathrm{Y}$ is output, $\mathrm{L}$ is labor, $\mathrm{K}$ is capital and $\mathrm{T}$ is land. According to Adam Smith output is therefore, related to labor and capital and land inputs. Furthermore, output growth was driven by population growth, investment growth and land growth as well as increases in overall productivity. Population growth was according to Smith endogenous because it depended how the increasing workforce was accommodated. Investment was also endogenous because it was determined by the rate of savings as well as land growth, which was dependent on the colonization of new lands or technological improvements of fertility of old lands. Technological progress could therefore increase growth. Smith also saw improvements in machinery and international trade as engines of growth as they facilitated further specialization.

Adam Smith's fundamental argument was that the division of labor or specialization improves growth. Smith also argued that growth was self-reinforcing as it creates increasing returns to scale.

The growth model of Adam Smith remained the predominant model of Classical Growth. In the other classical work of David Ricardo (Ricardo, 1817) he modified Smith's growth model by including diminishing returns to land. According to him, output growth requires growth of factors of production, but unlike labor, land cannot be increased because it is variable in quality and fixed in supply. His 
argument was that as growth increases, more land must be taken into cultivation, but land cannot be created.

Two important effects for growth were highlighted by him. Firstly, increasing landowner's rents over time due to the limited supply of land should cut into the profits of capitalists and secondly, wage goods from agriculture will cause a rise in price over time which will then reduce the profits of companies as workers require higher wages.

This development according to him will reduce the growth as explained by Adam Smith. Ricardo however claimed that this decline in growth could be checked by technological improvements in machinery and the specialization brought by trade.

These two classical economists, Ricardo and Smith as the first writers explaining the role of economics, stated from the early years that technology plays an important role in an enterprise. This was the foundation for later economists to developed further arguments about the important role of technology.

\subsection{Keynesian growth theory}

JM Keynes explained his Keynesian growth theory in his famous book The General Theory of Employment, Interest and Money (1936). Investment, in the Keynesian system, is an independent factor contingent upon the finance of entrepreneurs. It is however important to note that Keynes did not extend his theory of demand determined equilibrium into a theory of growth. The Cambridge Keynesians explored this scenario. This extension was developed by Sir Roy F. Harrod who together with Evsey Domar introduced the "HarrodDomar" Model of Growth between 1939 and 1946 (Domar, 1946).

Keynes's argument was that investment is one of the determinants of aggregate demand and that aggregate demand is linked to aggregate supply via the multiplier. In a goods market equilibrium the following equation can be written:

$\mathrm{Y}=(1 / \mathrm{s}) \mathrm{I}$

Where $\mathrm{Y}$ is income, I investment and $\mathrm{s}$ the marginal propensity to save, or $1 / \mathrm{s}$ is the multiplier. The difference about investment according to Harrod and Domar is that it increases the productive capacity of an economy and that investment should therefore change the goods market equilibrium (Domar, 1946). For "steady state" growth, in the language of Harrod-Domar, aggregate demand must grow at the same rate as the economy's output capacity grows.

The investment-output ratio, I/Y, can also be expressed as $(\mathrm{I} / \mathrm{K})(\mathrm{K} /$ $\mathrm{Y}) . \mathrm{I} / \mathrm{K}$ is the rate of capital accumulation which is thus the rate of 
capacity growth (call it "g") and $\mathrm{K} / \mathrm{Y}$ is the capital-output ratio (call it "v"). Thus, for a steady state growth $\mathrm{I} / \mathrm{K}=(\mathrm{dY} / \mathrm{dt}) / \mathrm{Y}=\mathrm{g}$ (i.e. the rate of capital accumulation or capacity growth and the real rate of output growth $(\mathrm{dY} / \mathrm{dt}) / \mathrm{Y}$, must be at the same rate, g). Thus, the equation can now be written as:

$\mathrm{I} / \mathrm{Y}=(\mathrm{I} / \mathrm{K})(\mathrm{K} / \mathrm{Y})=\mathrm{gv}$

According to the goods market equilibrium and from the multiplier, i.e. $Y=(1 / s) I$ which can be rewritten $I / Y=s$, the condition for full employment steady-state growth is $\mathrm{gv}=\mathrm{s}$, or simply:

$\mathrm{g}=\mathrm{s} / \mathrm{v}$

Thus, s/v is the "warranted growth rate" of output. If actual growth is faster than the warranted growth rate, then demand growth is outstripping the economy's productive capacity. Insufficient capacity implies that entrepreneurs will increase their production capacity through investment. With demand always one step ahead of supply, the Harrod-Domar model guarantees that unless we have demand growth and output growth at exactly the same rate, i.e. demand is growing at the warranted rate, then the economy will either grow or collapse indefinitely.

If the goods market equilibrium is analyzed, investment have to be equal to savings, $\mathrm{I}=\mathrm{S}$. If we follow the Keynesian axiom that investment is independent, then investment determines savings (or alternatively, aggregate demand determines aggregate supply).

However, profits are positively related to savings. Therefore, the following equation:

$\mathrm{I}=\mathrm{sP}+\mathrm{s}^{\prime}(\mathrm{Y}-\mathrm{P})$

\section{Which rearranging yields:}

$\mathrm{P} / \mathrm{Y}=\left[1 /\left(\mathrm{s}^{-\mathrm{s}^{\prime}}\right)\right](\mathrm{I} / \mathrm{Y})-\mathrm{s}^{\prime} / \mathrm{s}^{-\mathrm{s}^{\prime}}$

In other words, given the marginal propensities to save of all the population classes, the relative size of profits in income is dependent only on the investment decision, I/Y. It is thus clear from this Keynesian literature that more investment plays an important role in any economy. This investment can therefore also be in technology.

Joan Robinson (1962), one of the Keynesian followers, recommended a modification to understand the properties of this model better. The full employment relationship, i.e. I/Y $=\mathrm{gv}$, or the steady state growth must be qualified regarding what determines investment. In a Keynesian world, an independent investment function should 
remain independent. Therefore, Robinson posited a relationship I/Y $=f(P / Y)$ or $g=f(r)$, where investment decisions by firms were functions of (expected) profit. Robinson therefore tried to answer the question of stability, namely what guarantees that the profits generated by the above relationship will themselves generate the amount of investment needed to sustain them?

\subsection{Neoclassical growth theories}

In the Harrod-Domar growth model, steady-state Neoclassical growth theories was however unstable. It was a "knife-edge" scenario. Any deviation from the path would result in a further move away from that path. However, Robert M. Solow (1956), Trevor Swan (1956) and later, James E. Meade (1962) contested this conclusion. They claimed that the capital-output ratio of the Harrod-Domar model should not be regarded as exogenous.

They developed a new growth model where the capital-output ratio, $\mathrm{v}$, was the adjusting variable that would lead a system back to its steady-state growth path. This means that $\mathrm{v}$ would move to bring $\mathrm{s} / \mathrm{v}$ into equality with the natural rate of growth (n). Their resulting model became famously known as the "Solow-Swan" or simply the "Neoclassical" growth model (Dornbusch et al, 2004:61).

The Neoclassical growth theory focuses on capital accumulation and links to aspects for example saving and technology. This theory begins at a point where the economy reaches a long-run level of output and capital, which is called the steady state equilibrium. The next figure presents the production function in terms of GDP per capita relative to the capital-labour ratio. It is important to notice that the capitaloutput ratio, $\mathrm{v}=\mathrm{K} / \mathrm{Y}=\mathrm{k} / \mathrm{y}$, is captured as the slope of a ray from the origin to production function. Thus, changing $\mathrm{k}$ will change the ray and thus v. Unlike the Harrod-Domar model, $v$ is not exogenously fixed.

The shape of this function can also be explained because of the existence of diminishing marginal product of capital. It means that as capital rises, output rises as new machines are employed, but each additional machine adds less than the previous machine. The equation for the production function is written as $y=f(k)$

An economy is in this steady state equilibrium where per capita income and capital are constant, which is denoted as $\mathrm{y}^{*}$ and $\mathrm{k}^{*}$ (Dornbusch et al, 2004:63). These two values indicate the position where the investment required to provide capital for new workers and to replace old machines is equal to the saving that is generated 
in the economy. If saving is bigger than the investment requirement, then the capital per worker will rise over time and the output will rise accordingly.

\section{Figure 2. Per capita production function}

Source: Dornbusch et al (2004:62)

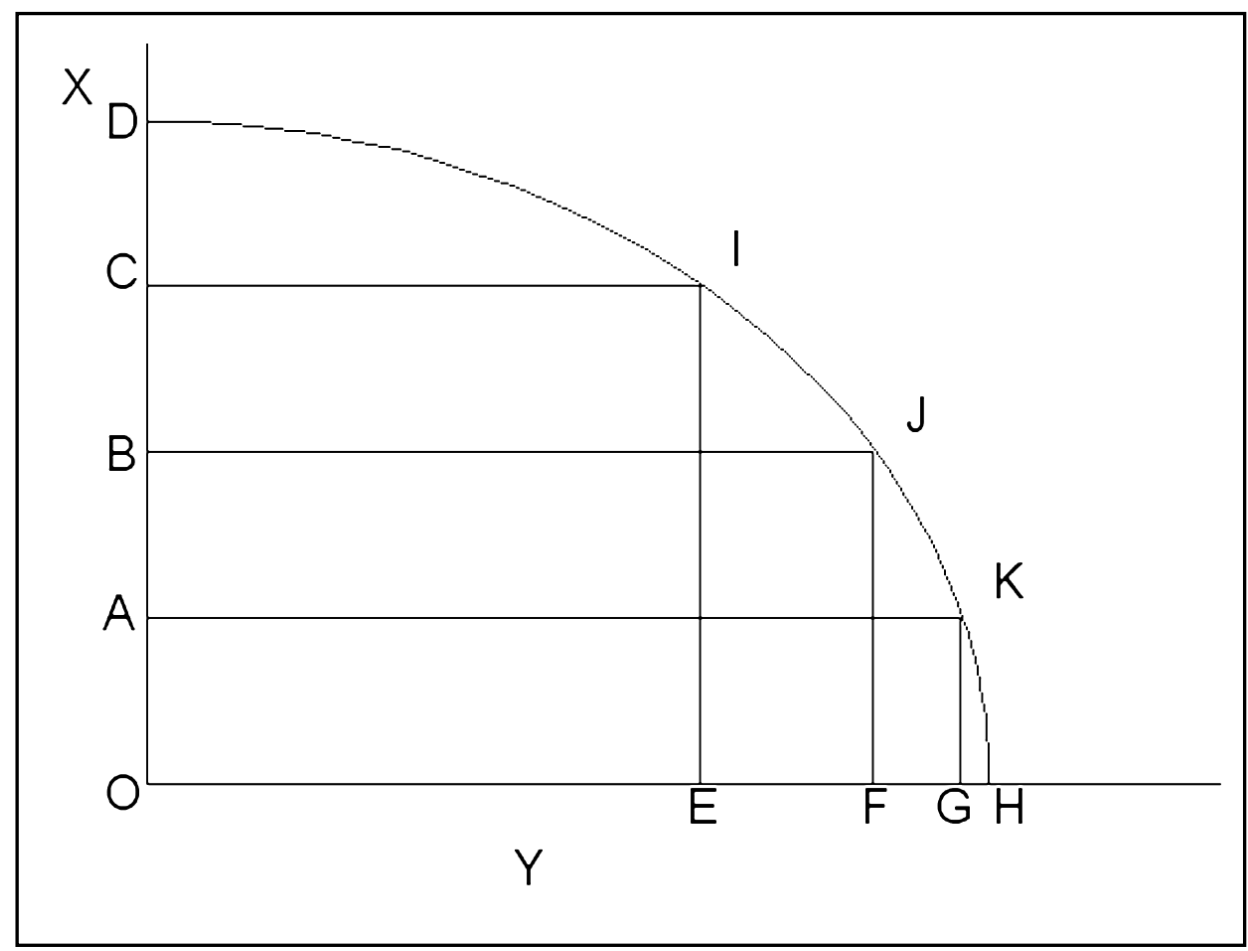

The investment required to maintain a given level of $k$, depends on the population growth and the depreciation rate of the capital employed in the production process. If it is assumed that the economy grows at a constant rate $n$, the economy therefore needs investment $n k$ to provide the necessary capital for any new workers.

If a constant depreciation is assumed, $d k$ can be written as the requirement for new machinery and equipment. The equation for the investment that is required to maintain a constant level of capital 
per capita can thus be written as

$(\mathrm{n}+\mathrm{d}) \mathrm{k}$

The next step is to incorporate saving. If it is assumed that no government sector and no foreign sector exist and that saving is a constant fraction of income, then per capita saving can be expressed as sy. Since income equals production, the following function can be written

sy $=\operatorname{sf}(k)$

The steady state of growth is defined where the change in capital is zero and it occurs at the values of $\mathrm{y}^{*}$ and $\mathrm{k}^{*}$. The steady state equation is therefore

$\mathrm{sy}^{*}=\operatorname{sf}\left(\mathrm{k}^{*}\right)=(\mathrm{n}+\mathrm{d}) \mathrm{k}^{*}$

We can depict the steady-state $\mathrm{k}^{*}$ in the following graph by superimposing the required investment function on top of our old diagram. At point $\mathrm{C}$ saving and the required investment balance with the steady state $\mathrm{k}^{*}$. The steady state income is read on the vertical axis according to the production function at point D.

The important point of understanding the Neoclassical growth model is when saving sy exceeds the required investment, then $k$ should increase. This occurs in the graph at the capital output ratio $k_{o}$ or at point A where the saving exceeds the investment needed to hold $k$ constant at the actual investment point $B$.

If the initial stage of the economy is $k_{0}$ then the adjustment process will take place and the economy will move to $\mathrm{k}^{*}$ or point $\mathrm{C}$.

The exact matching of actual and required investment is the steady state and the capital labour ratio neither rises nor declines. 


\section{Figure 3. Steady state output}

Source: Dornbusch et al (2004:66)

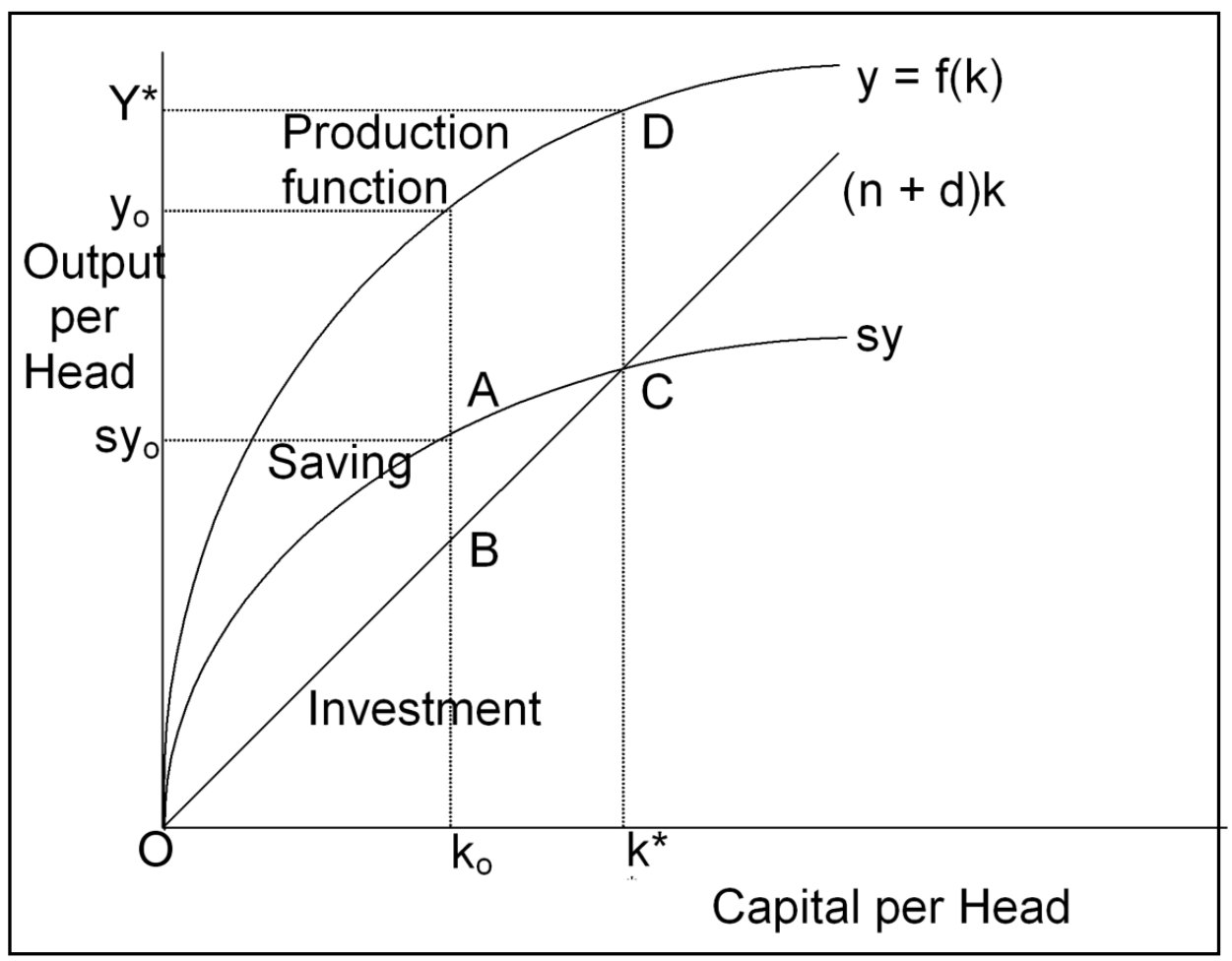

The Neoclassical growth model as illustrated in the next graph shows how an increase in the saving rate raises the growth rate of output in the short run. It does not affect the long run growth rate of output, but it raises the long run level of capital and output per head.

If the inhabitants of a country save a larger portion of their income, $\mathrm{s}^{1}$ rather than $\mathrm{s}$, the initial saving schedule will move upward to $\mathrm{s}^{1} \mathrm{y}$.

This higher saving is more than required to maintain capital per head.

The economy will move to a new steady state position where $\mathrm{k}^{*}$ moves to $\mathrm{k}^{* *}$ and therefore $\mathrm{C}$ to $\mathrm{C}^{1}$. At this higher point, saving is again enough to maintain the higher stock of capital. 
Figure 4. Increase in saving

Source: Dornbusch et al (2004:67)

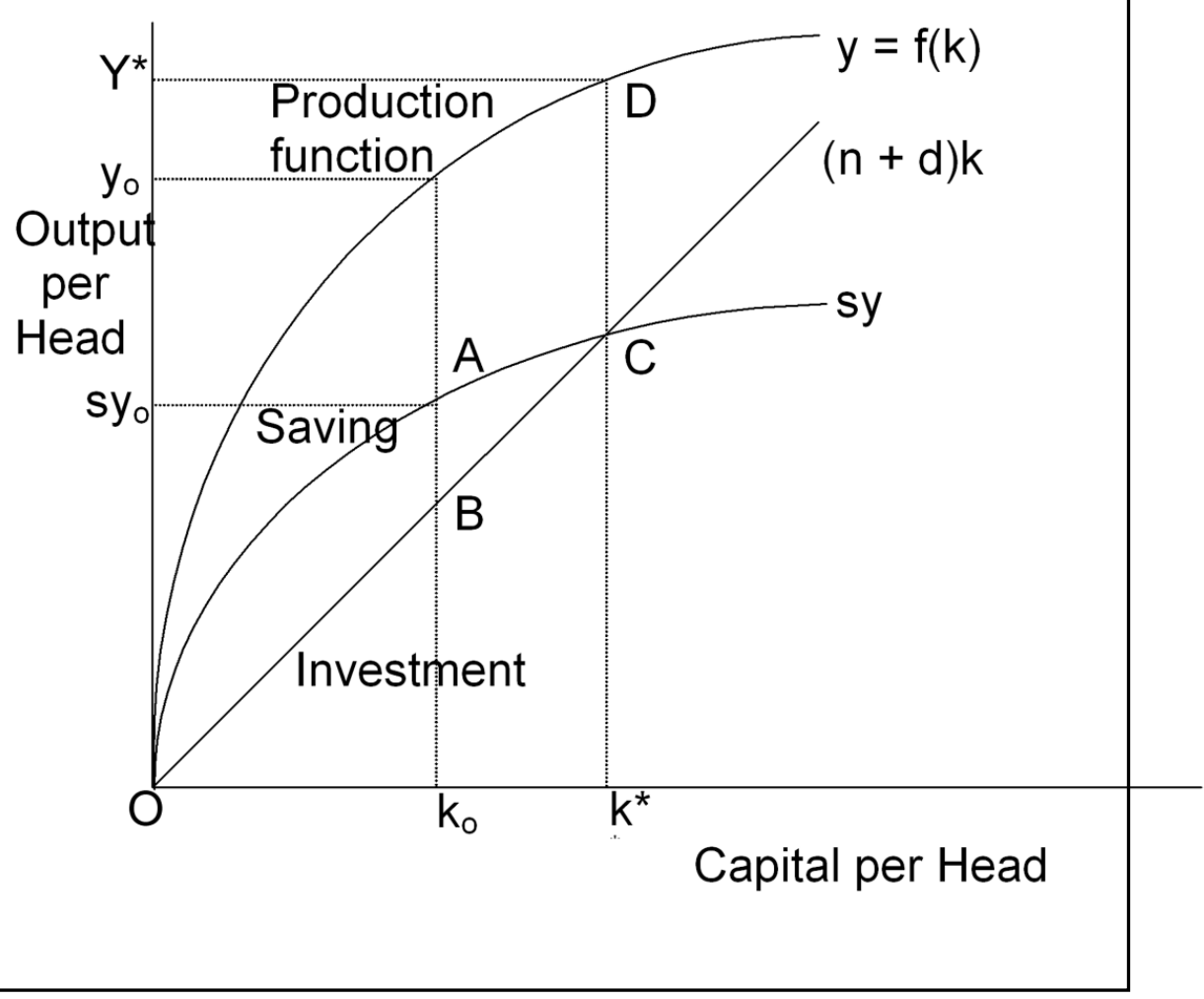

According to Dornbusch et al (2004) various empirical studies proved that the higher the rate of investment, either in physical or human capital, the higher the GDP of a country. The production function illustrated in the first graph can be thought of as a snapshot of a typical economy at a specific point in time. If we allow technology to be incorporated in the model then $\mathrm{y}$ will move from $\mathrm{y}_{0}$ to $\mathrm{y}_{1}$ to $\mathrm{y}_{2}$ over time as is indicated in the next graph.

An exogenous increase in technology thus causes the production function to rise as illustrated in the next graph. As the economy moves to a higher steady state the saving curve also rises. The result of this new higher steady state is a higher per capita output and a higher capital labour ratio. This is an important conclusion of this well- 
known growth theory, namely that increases in technology result in growth of output over time.

Figure 5. Exogenous technological change

Source: Dornbusch et al (2004:69)

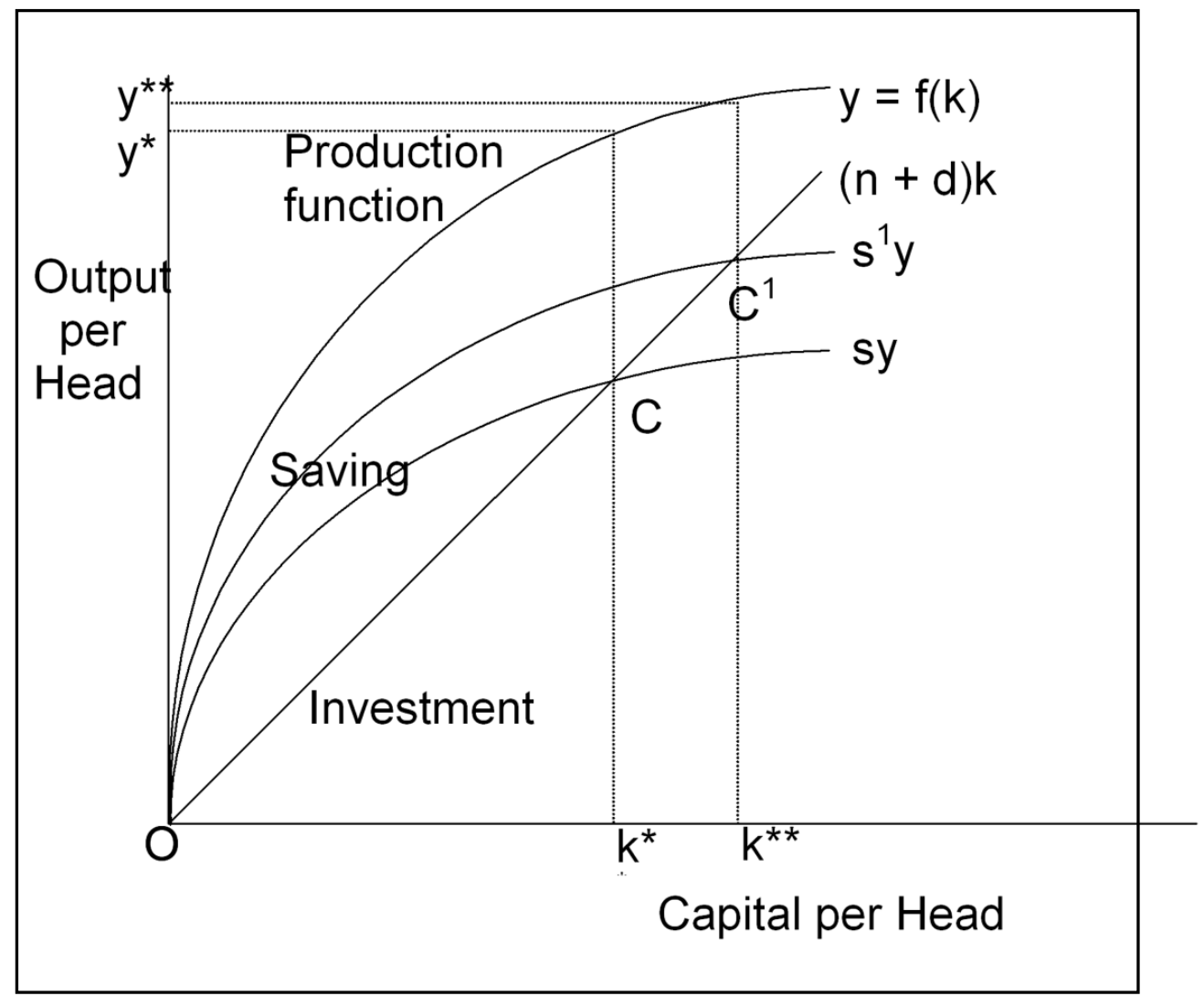

\subsection{Endogenous growth theory}

The Neoclassical growth theory dominated economic thought for three decades because it explained much of what was observed in the world. Neoclassical growth theory attributes the long-term growth to technology but do not explain the economic determinants of the technological progress. The solution to the problems experienced with 
the neoclassical theory was to modify the production function to allow for self-sustaining endogenous growth. The endogenous growth theory therefore studies the determinants of the technological progress (Dornbusch et al, 2004:79).

If we recall from figure 3 that $C$ is the steady state, it means that saving and investment is in balance. Any point where the saving line is above the investment requirement line, the economy is growing because of the capital invested in the economy. The question can be asked how this process will eventually comes to a steady state position of no change.

The answer is three fold, namely because of the diminishing marginal product characteristics of capital, the characteristics of the production function and the parallel savings curve that eventually flattens out. The investment requirement line has a constant positive slope, therefore the investment requirement line and the savings curve has to cross eventually.

The following graph explains the endogenous growth scenario. The shape of the production has changed and it now shows a constant marginal product of capital. The production function is now a straight line, like the parallel savings curve. The savings curve no longer flattens out; therefore saving is continuously greater than required investment. The graphical illustration clearly shows that the higher the saving grows, the bigger the gap of saving above the required investment and the faster the growth should be.

The following equations summarize this theory:

$\mathrm{Y}=\mathrm{aK}$

Where the marginal product of capital is the constant $a$ which means that output is proportional to the capital stock.

If we assume that the saving rate is constant at $s$ and there is no population growth and no depreciation of capital, we can write

$? \mathrm{~K}=\mathrm{sY}=\mathrm{saK} \quad$ or $\quad ? \mathrm{~K} / \mathrm{K}=\mathrm{sa}$

This means that the growth rate of capital is proportional to the savings rate and since output is proportional to capital, the growth rate of output is therefore

?Y $/ \mathrm{Y}=\mathrm{sa}$

which means the higher the saving rate, the higher the growth rate of output. 


\section{Figure 6. Endogenous growth}

Source: Dornbusch et al (2004:80)

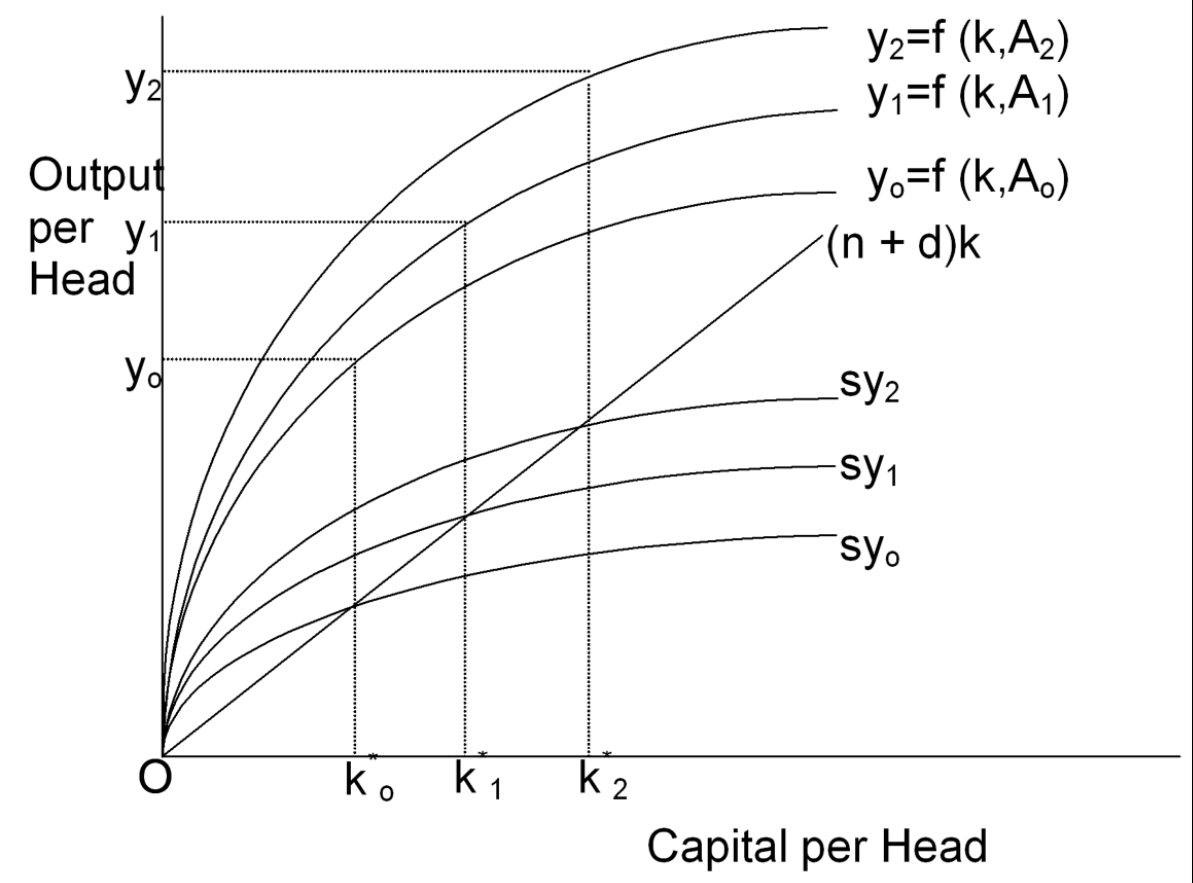

If we summarize the endogenous theory we come to two important conclusions:

- It relies on constant returns to scale to accumulate factors of production to generate ongoing growth. This means that a company with twice as much machinery and equipment will produce twice as much output. If the production factor capital is doubled, it means that output will also double, but if all the factors of production double, it means that a bigger output will be doubled. If there are constant returns to scale to capital alone, there will be increasing returns to scale to all factors taken together. This suggests that larger companies are more efficient, so that a single company can eventually dominate the economy in a specific sector (Dornbush et al, 2004:81). 
- Furthermore, the microeconomics that supports this theory emphasizes the difference between social and private returns when companies are unable to capture some of the benefits of investment. Investment produces not only new machines, but also new methods of doing the same thing. It may happen because of investment in research and sometimes because of spin-offs. If a company invests in a new machine or technique, management will capture the benefits of the machines or techniques, but it is in general harder to capture the benefits of new ideas and methods because it is easy to copy. This theory therefore also considers the role of human capital. Economists therefore think that investment in human capital in general and research and development are the keys to long run growth (Dornbush et al, 2004:81)

\subsection{Multi-sector growth theory}

Other economists tried to improve on the two important growth theories as explained in the previous section. Two-sector extensions of the Solow growth model were introduced by Hirofumi Uzawa (1961, 1963), James E. Meade (1962) and Mordecai Kurz (1963). This line of research however evaporated in the 1970s as suddenly as it had appeared. Hirofumi Uzawa's $(1961,1963)$ two-sector growth model considered a Solow growth model with two produced commodities, a consumer good and an investment good.

\subsection{Optimal growth theory}

Another theory to consider in this regard is the optimal growth argument. As far back as Eugen von Bohm-Bawerk (1889), economists discussed the idea that people tend to underestimate their future needs and desires and therefore "discount" their future utilities. These studies confirm the important role of planning in today's world and the important role of expenditure on capital goods and technology.

The Cambridge economist Arthur C. Pigou (1920) posed an interesting conundrum: He argued that if people tend to underestimate their future utility, they will probably not make proper provision for their future wants and thus personally save less than they would have wished had they made the calculation correctly. Pigou therefore argued that because of this lack of provision for future needs, it means that savings, as a whole, are less than what is optimal. He explains: 
Generally speaking, everybody prefers present pleasures or satisfactions of given magnitude to future pleasures or satisfactions of equal magnitude, even when the latter are perfectly certain to occur. But this preference for present pleasures does not imply that a present pleasure of given magnitude is any greater than a future pleasure of the same magnitude. It implies only that we, therefore, see future pleasures, as it were, on a diminished scale....This reveals a far-reaching economic disharmony. For it implies that people distribute their resources between the present, the near future and the remote future on the basis of a wholly irrational preference. (Pigou, 1920:24).

Numerous researchers independently examined the question of optimal savings for the Neoclassical model. The Cambridge philosopher Frank P. Ramsey (1928) proposed an intertemporal social welfare function and then tried to obtain the "optimal" rate of savings as the rate, which maximized "social utility" subject to some underlying economic constraints. This "golden rule" for efficient growth, as it has been called, was analyzed by among others Edmund S. Phelps (1961), Joan Robinson (1962) and Trevor Swan (1963). The answer was quiet simple: the optimal rate of savings will be that which makes the rate of return on capital equal to the natural rate of population growth.

\section{A revision of technology and growth}

\subsection{Leontief's technology theory}

Leontief had a unique focus and believed that economic analysis is worthless unless the variables can be measured. He simply described the interdependence of sectors in quantitative terms and explored the nature and the consequences of that interdependence. He developed an input-output model (for which he received a Nobel price) which constituted a recipe for each sector's output.

According to (Leontief, 1941) this matrix of proportions (or inputoutput coefficients) for all sectors therefore serve as a map of the economy's structure.

Neoclassical economists saw input-output ratios as the outcome of market processes, where prices mediate choice among a series of "given" technological options, sometimes represented by isoquants.

Leontief recognized that economists had little or no systematic information on those "given" technological options, which limited their discipline to theoretical speculation. 
If we consider a technology in which there are only two possible techniques, we can use isoquants to describe the scenario. According to (Leontief, 1941:38) in each technique there is no possibility of substituting one input for another, but various mixes of the two techniques that can be used by the firm. This is explained with two machines that can be operated at two possible speeds, fast and slow. If they run fast, then a relatively small amount of labor is used together with a relatively large amount of raw material because there can be waste of materials. If they run slowly, then a relatively large amount of labor is used together with a relatively small amount of raw material. The firm can run some of its machines fast, and some slowly. An isoquant for such a technology has the form as described in the following figure if we consider only raw material and labor as inputs.

\section{Figure 7. Isoquant technology}

Source: http: / / www.economics.about.com/od/ famouseconomists Date of access: 14 July 2007.

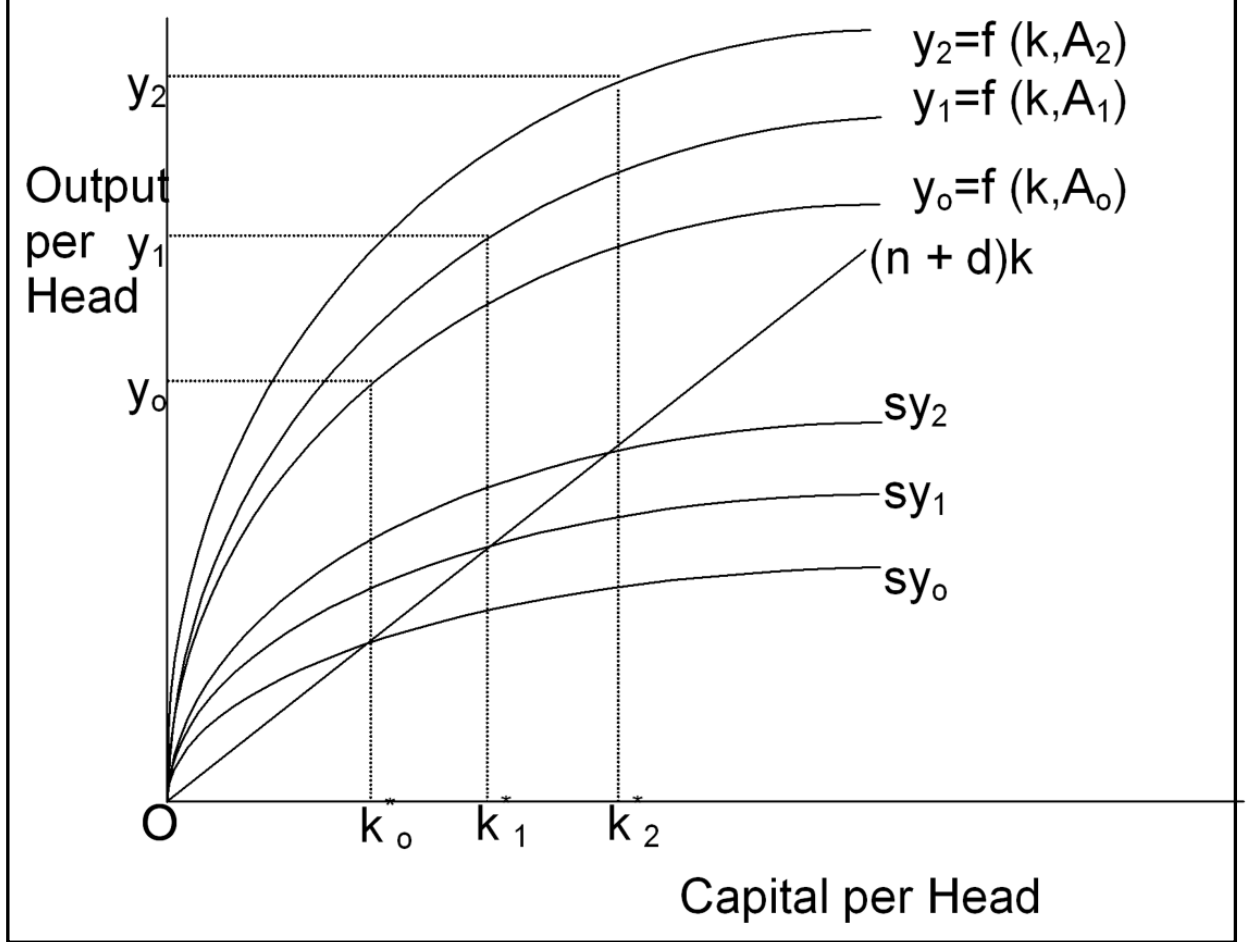


The corner A of the isoquant corresponds to the case in which all the machines in the factory run fast and corner B correspond to the case in which they all run slow. The points in between, on the downward sloping section, correspond to cases in which the firm runs some of its machines fast and some slowly.

The concept of marginal productivity from micro economics relies upon the idea that a particular factor can be added to a production process while all the other factors remain constant. In the production function, $\mathrm{Y}=\mathrm{f}(\mathrm{K}, \mathrm{L})$, the technique of production at any particular point is merely the capital-labor ratio, K/L. If we refer to technology as the set of feasible techniques available to the producer, we can use the isoquant analysis to describe this process. If the producer wishes to produce a particular desired level of output, $\mathrm{Y}^{*}$, then the technology the producer must have available are all the capital-labor ratios matching the points on the relevant isoquant.

The implied L-shaped isoquants of such a production function is illustrated in the graph above. Such a technology is referred to as "Fixed Proportions" or "Input-Ouput" technology according to Leontief.'s contribution. At any particular output level $\mathrm{Y}^{*}$, there is a necessary level of $\mathrm{K}^{*}$ and $\mathrm{L}^{*}$ which cannot be substituted. To increase only labor inputs will not result in any higher output. The extra labor, without the extra capital to work in combination, will be entirely wasted. This analysis of Leontief allows companies to choose among different production processes and factors (technology as one of five factors) to create optimum growth.

A more flexible version of this type of economy developed, namely the activity analysis production technology. This version was introduced by various economists, for example P.A. Samuelson and R. M. Solow (1958). In this activity analysis, producers can choose among a small, finite number of distinct production processes or activities. The advantage of activity analysis models over earlier Leontief models is that we are not constrained to using only one activity. Analysis of isoquants allows companies not only to choose among several different production processes, but thus also any combination of production processes.

\subsection{A Last Thought about steady state growth}

To conclude an interesting comparison is done between a world with no growth and one with high growth. It is therefore a combination of elements of the neoclassical and endogenous growth theories. We therefore have two kinds of investment opportunities illustrated in the graph. One with diminishing marginal product as in the neoclassical growth model at low income levels and one with a constant marginal product as in the endogenous growth model at 
higher income levels (Dornbush et al, 2004:84).

Neoclassical growth equilibrium is illustrated at point $A$ and endogenous growth equilibrium is illustrated at point B. At low income and capital, the capital requirement line strikes the saving line in the neoclassical no growth steady state. At high income and capital the saving line is above the capital requirement line, leading to ongoing growth. This comparison highlights a very important point. As societies invest, they can choose between two kinds of investments. Societies that direct their investment towards research and development will have ongoing growth. Societies however, directing their investment towards physical capital may have higher output in the short run at the cost of lower long run growth.

Figure 8. Steady state versus growth

Source: Dornbush et al (2004:84)

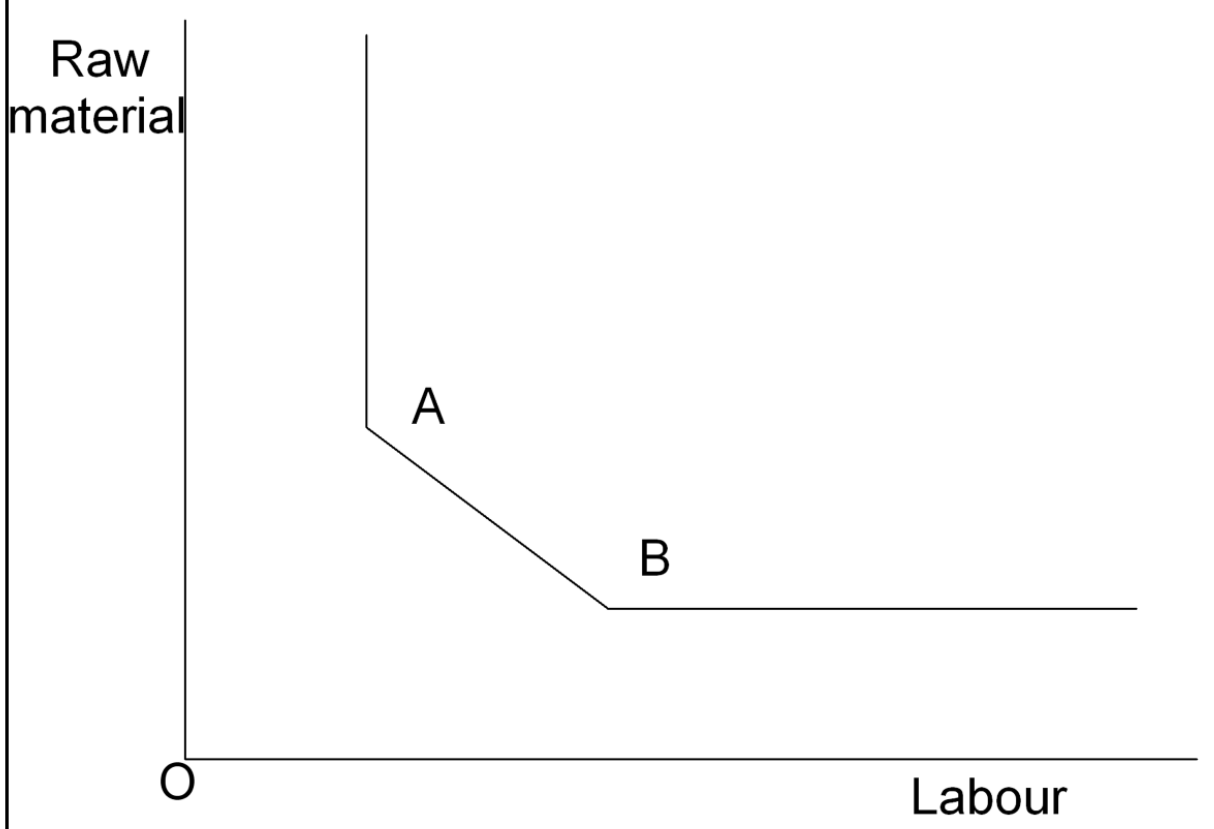




\subsection{A last thought about growth theories}

The relationship between technology and economic growth were captured in a vast number of formal models over a long time in the previous century. Early Neoclassical models like Solow (1956) treated technical change as an exogenous variable, illustrating how longrun economic growth only depended on (exogenous) technical change.

Arrow (1962), who endogenized technology by assuming learning by doing, stated that it grew at a constant rate, and found that long-run economic growth crucially depends on population growth. Other important contributions in the 1960 s were made by Uzawa (1965) and Phelps (1966) among others, who all related technology growth to some specification based on labour resources devoted to the development of new technologies and ideas. On the other hand, the more recent type of models of the endogenous growth literature by for example Romer (1990) and Aghion and Howitt (1992) all share the characteristic that a continued increase in the level of resources spent on the creation of new technologies leads to a continued increase in economic growth.

A group of models that emerged in the course of the 1980s explains long-term economic growth endogenously, by relaxing the assumption of diminishing returns to capital and by rendering technological progress endogenous to the model. According to these studies output and productivity growth do not rely on exogenous technical progress. In a pioneering paper, Romer (1986) analyzed that research and development (R\&D) activities are associated with externalities, which affect the stock of knowledge available to all firms.

In Vodafone's Third Policy Paper and its publication on the "Impact of Mobile Phones in the Developing World", there are referrals to several studies done on South Africa and other countries in Africa that are using mobile phones. The facts explained in the previous paragraphs are confirmed by this Vodafone study in Africa. The following paragraph is an extract from this Third Policy Paper. It reads:

The developing world does have huge capacity for natural growth in basic services but is severely constrained in terms of economies and infrastructural digital constraints. Some governments in developing regions have ambitious expectations of socio-economic transformation through ICT but they may not fully perceive the commitment required to methodical long-term strategies for synergising its establishment and proliferation. This is a challenge because the ICT industry alone cannot effect socio-economic 
transformation. Network operators can and do contribute much through ICT both directly through the services they provide and indirectly through taxes and corporate social responsibility programmes, but their focus has to be business viability (Vodafone Future Vision 2007, vol.2, chapter 3: The emerging world, South Africa and Africa in the global context).

\section{Technology and mobile phones in developing countries}

\subsection{Introduction}

Economists have become accustomed to associate long-term economic growth with technological progress as it is embedded in the Solow growth model and in the endogenous growth model. The more modern literature views technology as being produced within the system by the rational and purposeful application of research and development and the growth of complementary human and physical capital. It does not matter which theory is used as a basis of reasoning, technology is central to the dynamics of any economy. People are inherently innovative and if the circumstances are right, technological progress is guaranteed.

The essence of technology in modern times is that it is not stationary. Technological change has become self-propelled and autocatalytic, in which change feeds on change. The period that followed the Industrial Revolution was one in which innovation intensified. There were ebbs and flows, in which major breakthroughs occurred and macro inventions were followed by waves of micro inventions with secondary applications (Mokyr, 2005). The dynamics of technology are that the present and the future are nothing like the past.

\subsection{Economical growth in the current information age}

Technology is one of the drivers of growth. The pace of invention and innovation increases the speed of economic progress. Several factors contribute to this process (Federal Bank of Dallas, Policy Backgrounder no 147, 1993 p3):

- The breadth and depth of a society's existing endowment of technology,

- New discoveries or inventions with wide-ranging uses,

- The integration of various technologies to create new products, 
- $\quad$ The time it takes for products to spread throughout society and

- The overall market size

To assess future possibilities, it is useful to look at the different factors that accelerate technological changes. Firstly, the inventory of technology is large and growing. The number of scientists and engineers working in research and development has increased and therefore companies are likely to offer innovative goods and services at a continuous pace. Secondly, all inventions are an effort to raise the living standards of a country's inhabitants, but some inventions are clearly more important than others are. From time to time, an invention comes along that really rocks the world because it has farreaching applications.

Thirdly, each invention makes the next one easier because of the spillover effect because one technology fueling the development of another. A perfect example is the inventions that were necessary for the development of the personal computer. The invention of the microchip is another example that already enabled the invention of thousands of other consumer products. Fourthly, new products are spreading faster.

In the information age lightning-fast communications spread information faster and consumers grow more sophisticated and new products are emerging more quickly than in the past. New products follow a certain pattern. At first, the latest innovations are expensive and perhaps tricky to use, but over time, the products become cheaper and more consumer-friendly through mass production and improved design.

Lastly, as markets are getting larger, it increases the incentive to introduce new technology. Various factors influence the size of the market. Population growth is only one way markets grow. Rising incomes add to the number of people who can afford certain products, for example the new middle class or "black diamonds" in South Africa. Faster information flows can also enlarge markets and the dismantling of trade barriers can open new markets for a country. The NEPAD project is a perfect example.

\subsection{Need for technology in africa}

Information technology does not only determine the market share and profitability of individual companies in tomorrow's global economy, but it has a huge impact on future generations of workers

TD, 3(2), December 2007, pp. 351-394 
and on a country's economic prospects. The obvious question is then what are the implications of information technology for the relative fortunes of African nations? The answer is that countries that invest in and adopt information technology will move ahead and those that fail to rapidly adopt information technology will be left behind (African Development Bank, Research Paper, s.a.).

Despite the recent efforts to liberalize and improve telecommunication services, access to the global information infrastructure by African countries is still far from adequate. African governments and companies need to invest in telecommunications, as a priority sector, if it is to stand a chance in the emerging global competitive environment. This is particularly the case as Africa is classified, based on telecommunication revenues and investment, to be among the least possible regions to achieve convergence to the standard of services in developed countries in the future.

To exploit these opportunities, African countries need, as a matter of priority, to upgrade their capabilities through the improvement of their telecommunication infrastructures (African Development Bank, Research Paper, s.a.). Governments have to facilitate information transmission by passing the necessary laws and regulations. It is essential to reduce or abolish import taxes on information technology hardware such as computers, printers, satellites, televisions and radios. According to this study of African Development Bank, in some African countries technology equipment are treated as luxury items and hence, heavily taxed. These desired improvements need to be pursued within the framework of comprehensive national or subregional plans to link African countries to each other and to the global information technology infrastructure.

\subsection{Studies in Africa}

Theory explains that technology plays an important role in economic growth. In this section various studies regarding the role of mobile phones in the OECD countries and Africa are referred to. These studies explain the positive impact of mobile phones on economic growth, as well as the benefits to communities and small businesses of certain African countries.

6.4.1 In research done by Vodafone\{Waverman, L. et al: Vodafone Policy Paper Series, 2005 (3)\} regarding the use of mobile phones in developing countries it was found that the own-price and income elasticities of mobile phone demand was significantly above one. In microeconomics a value less than one means that the response is small and thus inelastic. A value of more than one means that the response is big and thus elastic. The value above one therefore means 
that demand increases were much more than in proportion to either increases in income or reductions in price. This research also proved that in developing countries mobile phones are good substitutes for fixed-line phones.

In earlier history telecommunications networks helped to generate economic growth by enabling firms and individuals to decrease transaction costs and firms to widen their markets Mokyr (2005). In more recent times, Roeller and Waverman (2001) analyzed the impact on GDP of investment in telecommunications infrastructure in the OECD between 1970 and 1990 .

They showed that it significantly enhanced output, allowing for the fact that the demand for telecoms is itself positively related to GDP.

According to this study, it is important to consider that the telecoms penetration in 1970 was quite low in a number of OECD countries. France had 8 phones per 100 inhabitants, Portugal 6 and Italy 12 . The study proved that the spread of modern telecommunications infrastructure between 1970 and 1990 generated economic growth over and above the investment in the telecoms networks itself.

In 1995, just under half of the membership of the International Telecommunications Union (ITU), an international organization comprising 214 countries, had telecoms penetration rates below 8 phones per 100 inhabitants, the level attained by France in 1970.

Much of the world still lacked a major component like the telephone as a modern, efficient economic system in 1995. In the 1970 to 1990 period analyzed by Roeller and Waverman, mobile phones were not important: telecoms networks were fixed-line systems. Today, however when telephone networks are considered, the importance of mobiles stands out, especially if examined for the 102 members of the ITU that had low phone penetration rates in 1995.

According to this research, it is clear that telecommunication systems are largely mobile systems and not fixed lines in developing countries. The reason for this fact is the lower cost that is associated with mobile systems as compared to higher cost of fixed lines. According to thi $\mathrm{s}$ research, it is estimated that a mobile network costs approximately 50 percent less per connection than fixed lines and also that it can be rolled out faster. Further cost advantages of mobile phones as a development tool consist not only of the lower costs per subscriber but the greater modularity of mobile systems also influences the potential buyers.

6.4.2 In another research project done by Vodafone \{Coyle, D: Vodafone Policy Paper Series, 2005 (3)\} the universally rapid spread of mobile phones in the developing world was analyzed. The following 
contributing factors were identified:

- The shorter payback period on investment compared to a fixed line system and lower installation costs than fixed lines, for example in India up to six times lower than the estimated $\$ 1000$ variable cost per additional fixed line -Complementary with lower levels of skills than what is needed for computers or the internet. Especially important for providing technological access to the poorest people, who are much more likely to be illiterate and speakers of minority languages

- Potentially lower social/income entry barriers than the internet, due to lower up-front expenditure. Compared to fixed lines because of greater ease of sharing mobile handsets

- Business model innovations, i.e. pre-pay which helps overcome credit barriers and the use of mobile phones as public telephones

- Network effects which generate rapid momentum once critical mass is reached

- Greater ability to overcome geographic hurdles eg mountains and deserts. Bhutan is an extreme example where the mountains were unsuitable for the installation of fixed line telephony at all. Mobile phones are also less vulnerable to natural disasters than fixed telecoms

- Competition with fixed incumbents, stimulating the growth of the telecommunica-tions market. The poorest developing countries are still substantially less likely to have reformed their telecoms markets

- Roll-out requirements in licenses. Specific requirements for rollout in rural and low-income areas were found in Ghana, South Africa and Uganda.

According to this report the growth impact of mobiles is large in both developed and developing countries, but around twice as important in the latter group. This has a major policy implication for developing countries. The cost of wireless technologies are much lower to implement over large areas than fixed line systems, therefore mobile phones can potentially play an important role in economic development. It should therefore be worth investing large amounts in telecommunications in developing countries.

6.4.3 In another research project done by Vodafone three 
countries were surveyed to establish the impact of mobile phones on the community and on small businesses.

\section{Table 1. Fixed lines and mobile lines per 1000 people for egypt, South Africa Tanzania}

\section{Source: \{Samuel, J.et al: Vodafone policy paper series, 2005 (3)\}}

\begin{tabular}{|c|c|c|c|c|c|}
\hline Country & Population & $\%$ URBAN & Per CAPITA GDP & FIX & Mobile \\
\hline EGYPT & 70.5 & 42.1 & 3,810 & 110 & 67 \\
\hline South Africa & 44.8 & 56.5 & 10,070 & 107 & 304 \\
\hline TANZANIA & 36.3 & 34.4 & 580 & 5 & 22 \\
\hline Developing Countries & 4,937 & 41.4 & 4,054 & 96 & 101 \\
\hline High Income Countries & 941.2 & 77.8 & 28,741 & 584 & 653 \\
\hline WORLD & 6225.0 & 47.8 & 7,804 & 175 & 184 \\
\hline
\end{tabular}

According to this survey, it was established that the perception of ownership of mobile phones in Tanzania is different to that in South Africa. When the respondents stated that they owned a mobile phone, they often considered it as a household asset rather than a personal or individual one.

This was particularly the case for female respondents. However, cultural norms in rural Tanzania dictate that ownership of such items lies with male members or heads of the households. Nearly 57 percent of the respondents who owned a mobile phone in South Africa were female. Similarly, 60 percent of respondents who were users but not owners were also female.

Another aspect established in the survey and not surprisingly, almost half of the respondents who were users in the South African communities came from the 25-45 age groups. The respondents in this age group are economically active and therefore may be more likely to own a phone. However, respondents in age groups of 46-55 and over 55 were still well represented in the group of owners and 
users. In Tanzania however, the patterns of age distribution in the group of owners and users was similar to the pattern of South Africa, but was more concentrated in the age group of 26-45. In the next table, the results of these surveys are displayed.

\section{Table 2. Impact of mobile phones of respondents}

Source: $\quad$ Samuel, J. et al: Vodafone policy paper series, 2005 (3)\}

\begin{tabular}{l|l|l|}
\hline $\begin{array}{l}\text { IMPACT } \\
\text { PROMPTED RESPONSES }\end{array}$ & SA\% & TANZANIA\% \\
\hline IMPROVED RELATIONSHIPS & 78.7 & 85.3 \\
CALL RATHER THAN TRAVEL & 77.49 & 1.1 \\
TO FAMILY AND FRIENDS & & \\
UN-PROMPTED RESPONSES & & \\
EASIER COMMUNICATION & 72.2 & 84.6 \\
WITH FAMILY AND FRIENDS & & \\
USEFUL IN EMERGENCIES & 25.8 & 27.1 \\
ASSISTS IN JOB SEARCH & 15.5 & 2.7 \\
AVOIDS PROBLEMS WITH & 8.8 & N.A. \\
PUBLIC FIXED-LINE PHONES & 8.2 & 9.0 \\
EASIER TO ORGANIZE MEETINGS & 7.7 & 53.2 \\
FASTER OR IMPROVED & 7.2 & 34.0 \\
COMMUNICATION & \\
ACCESS TO BUSINESS & \\
&
\end{tabular}




\begin{tabular}{|l|c|c|}
\hline $\begin{array}{l}\text { IMPACT } \\
\text { PROMPTED RESPONSES* }\end{array}$ & SA\% & TANZANIA\% \\
\hline & & \\
INFORMATION/BUSINESS PURPOSES & & \\
SAVES MONEY & 5.7 & 1.6 \\
EASIER TO CONTACT & 4.6 & 5.9 \\
SCHOOL/UNIVERSITY & & \\
CONTACT EMPLOYER/ & 3.6 & 3.7 \\
CLIENTS ON ROAD & & \\
CAN SEND CHEAP MESSAGES & 2.6 & 0.5 \\
USING SMS & & \\
STATUS SYMBOL & 2.1 & - \\
IMPROVED ACCESS TO & 1.5 & 1.1 \\
TELECOMMUNICATIONS & & \\
\end{tabular}

* These impacts were identified through specific questions, while the rest of the impacts identified were offered by the respondents without a specific question being asked.

In addition to the community surveys, these researchers also explored the use of mobile phones by small businesses. Urban and rural businesses were surveyed in South Africa, but in Egypt only in Cairo. In the next table, the results of these surveys are displayed. 
Table 3. Impact of mobile phones on small businesses

Source: $\quad$ Samuel, J. et al: Vodafone policy paper series, 2005 (3)\}

\begin{tabular}{|l|l|l|}
\hline & EGYPT\% & SA\% \\
\hline PROMPTED RESPONSES & 67.3 & 47.1 \\
INCREASED CALL COSTS & 66.0 & 56.6 \\
INCREASED TURNOVER & 65.3 & 56.2 \\
INCREASED CUSTOMER NUMBERS & 58.7 & 61.8 \\
INCREASED PROFITS & & \\
UNPROMPTED RESPONSES & 57.3 & 25.7 \\
FASTER/IMPROVED COMMUNICATION & 56.0 & 21.4 \\
INCREASED EFFICIENCY & 24.7 & 10.0 \\
SAVE TIME & 23.3 & 47.1 \\
AVAILABLE TO CLIENTS ALL THE TIME & 22.0 & 15.7 \\
SAVE COSTS & 16.7 & 4.3 \\
LARGER CLIENT DATABASE & 15.3 & 21.4 \\
PLACE ORDERS ON THE JOB & 11.3 & 4.3 \\
BAD NETWORK & 10.0 & 20.7 \\
ASSIST IN BREAKDOWNS/ & 8.0 & \\
EMERGENCIES & 7.3 & 25.0 \\
REDUCED TRAVELING & & \\
CONTACT WITH THE OFFICE & & \\
LESS FREE TIME/ NO PRIVACY & & \\
& & \\
\hline
\end{tabular}


The results of these Vodafone surveys suggest that mobiles brought considerable benefits to communities and small businesses of certain African countries. The surveys indicated that people at all income levels are able to access mobile services, either through owning or sharing a phone and that gender, age and education do not seem to constitute barriers to access.

A very interesting observation was that income explains the level of usage but the lack of income does not prevent the use of mobile phones. The absence of electricity does not present a barrier, thanks to the sharing of mobiles and recharging batteries in the nearest town. Other methods are also used, for example the recharging locally by a generator or car battery.

Mobile phones brought for the residents of the rural communities positive economic and social impacts. Typical examples are that mobile phones reduced travel needs, assisted job hunting and provided better access to business information. Greater ease of contact with family and friends also brought improved relationships. These benefits were reported even though the communities surveyed were amongst the poorest in their countries.

Mobile phones have also become an essential tool for small businesses. A substantial proportion of small businesses have no alternative method of communication. This fact is applicable for black-owned businesses in South Africa and informal sector businesses in Egypt. This observation suggests that mobile phones are an important tool for disadvantaged groups. A large majority of small businesses, which were surveyed, said mobiles brought higher profits, turnover and increased efficiency, although they are paying higher call charges.

\subsection{International competitiveness for South Africa}

The National Research Foundation (NRF) published a policy document regarding economic growth and international competitiveness. The following paragraph is an extract of this document

South Africa must develop a competitive, sustainable, fast-growing economy that creates national prosperity. The extent to which this challenge is addressed will depend on a dynamic and multidisciplinary knowledge base capable of integrating technology, management and labour. The keys to building a competitive industrial base are knowledge, innovation and productivity. (www.nrf.ac.za Date of access: 9 July 2007). 
According to this policy document, technological change is an important source of development in our economy. Our economy remains largely dependent on natural resources, processing, manufacturing and on imported technologies. South Africa has to improve its international competitiveness. Economic growth and international competitiveness can improve if the transfer of knowledge and technology is properly managed. Technological innovations and applications is of utmost importance in a competitive international environment.

It is clear from this policy document that the South African government has a specific plan regarding economic growth, international competitiveness and the role of technology in this process of development. However, two questions originate, namely if the government has the infrastructure and manpower to effectively address all these issues. Secondly, if government will allow private institutions to effectively develop technology and other means for the improvement of South Africa and all its inhabitants.

\subsection{AsgiSA}

The ANC made a commitment in its 2004 election manifesto to halve unemployment and poverty by 2014. To accomplish this AsgiSA's objective for $2004-2009$, it is necessary to create an average growth rate of $4,5 \%$ per year. To accomplish the objective by 2014 a real growth rate of $6 \%$ must be achieved and sustained from 2010 (www.info.gov.za/documents/index Date of access: 9 July 2007).

The AsgiSA team identified six binding constraints that mitigate against the achievement of these growth rates. It is necessary to refer to these constraints in this document regarding technology and growth, because if these issues are not addressed and solved by government, the required growth rate and poverty levels will not improve. It is clear that one of the constraints is a lack of capacity of logistics in SA, which is crucial for the smooth development and growth of SA (www.info.gov.za/documents/index Date of access: 9 July 2007).

Two questions originate, namely if the government has the infrastructure and manpower to effectively address all these issues and secondly if government are serious to tackle all these obstacles to allow development in South Africa. The constraints highlighted in the first annual report of AsgiSA are as follows:

- The relative volatility of the currency 
- The cost, efficiency and capacity of the national logistics system 7. Comparison of Frequency Allocations Policy in USA and South Africa

\subsection{Summary of USA policy}

Various technology studies by Vodafone were referred to regarding Africa. In this section the policy regarding frequency allocations of a developed country is referred to. Their policy can be used as a guideline by South Africa and other African countries. In March 2004, the President of the United States of America announced that all Americans should have universal, affordable access to broadband technology by 2007 . Some of the new broadband technology is wireless.

The goal of this study was to promote the development and implementation of a U.S.A. spectrum policy for the $21^{\text {st }}$ century to foster economic growth, ensure their national and homeland security, maintain U.S.A. global leadership in communications technology. It also had to satisfy other U.S.A. needs such as public safety, scientific research, federal transportation infrastructure and law enforcement. (www.ntia.doc.gox/osmhome/frequencyallocations Date of access: 27 July 2007).

The recommendations proposed in this study build upon the experiences of the federal spectrum management community in its efforts to implement policies for three new technologies - third generation (3G) wireless, Wireless Fidelity (WiFi) and Ultrawideband (UWB). This policy summary in a developed country can be used as a guideline of what should happen regarding frequency planning and management in an emerging country like South Africa.

Fifteen recommendations were proposed to their existing spectrum management policy to meet their future spectrum needs effectively. The following six recommendations can be highlighted for the South African scenario. Firstly, advanced information technology capabilities should be used to modernize the existing paper-based processes and procedures associated with coordination of operations, assignment of frequencies and certification of new systems. Secondly, to ensure that the federal government procures only the most effective and efficient technologies and systems, each federal agency should implement a formal process to evaluate their proposed needs for use of the spectrum before seeking spectrum certification.

Thirdly, to ensure that the current uses of radio communication 
systems are as efficient as possible and to develop new policies for improvement as needed, the governing body should evaluate all spectrum use by the federal government over a five-year period to determine spectrum efficiency. Fourthly, the governing body should initiate a plan to identify and implement incentives that promote more efficient and effective use of the spectrum. This plan should also include the development of models to determine spectrum value.

Fifthly, the governing body should develop a plan to increase sharing of spectrum between federal government and non-federal government users. Lastly, the governing body should work cooperatively to review existing analytical and measurement processes used to determine the impact of new technologies and expanded services on incumbents to reduce the time it takes to assess new uses of the spectrum.

The six summarized points is a clear guideline for our policy makers to address our technology development effectively to increase our real growth rate and for the benefit of all the inhabitants of South Africa.

\subsection{Summary of policy and spectrum allocation in SA}

ICASA does not provide information about their policy regarding frequency allocation and specific frequencies that are assigned or allocated to operators. Various telephone calls were unanswered after messages were left to reply. Various emails were sent which were also unanswered. After continuous telephone calls the only response from ICASA was to supply a draft terrestrial broadcast frequency plan for 2007 by email which was not requested.

\section{Table 4. Size of different operators}

Source: SA telecommunications report Q3, 2007

\begin{tabular}{|l|l|}
\hline VodACOM & 57,9 MILLION SUBSCRIBERS OR $24,6 \%$ \\
MTN & 31,5 MILLION SUBSCRIBERS OR $13,4 \%$ \\
CELL C & 8,0 MILLION SUBSCRIBERS OR $3,4 \%$ \\
VIRGIN Mobile & 2,6 MILLION SUBSCRIBERS OR $1,1 \%$ \\
\hline
\end{tabular}


The above table illustrates the subscription between small and big operators in the private sector. In the table below is a summary of the frequency allocations as obtained from the market place as at end of 2007. ICASA could not or did not want to supply this information as indicated above. This information was eventually obtained from various market operators. Two important points are very clear from the size table and the frequency allocations table:

- The allocation between small and big operators in the private sector is the same. The available scarce frequency bands are according to this information not optimally allocated and go against all economic principles as discussed in the earlier theoretical section.

- The government institutions are favoured at the expense of the private sector operators. This information also goes against economic principles, for example the opportunity cost principle and illustrates the fact even more that frequencies are not optimally allocated to enhance economic growth.

If these allocations are indeed a true reflection of the current scenario it should definitely handicap economic growth and development in South Africa to the detriment of all of South Africa's inhabitants.

\section{Table 5. Frequency allocations allocated for different operators}

\section{Source: Various, market operators}

\begin{tabular}{|llll|}
\hline Operator & Frequency band & Spectrum allocated & Usage \\
Telkom & $2100 \mathrm{MHz}$ & $20 \mathrm{MHz}$ & UMtS \\
Telkom & $3.5 \mathrm{GHz}$ & $56 \mathrm{MHz}$ & WimAX \\
Telkom (Total) & $76 \mathrm{MHz}$ & & \\
& & & WiMAX \\
Sentech & $2500 \mathrm{MHz}$ & $50 \mathrm{MHz}$ & WiMAX \\
Sentech & $3.5 \mathrm{GHz}$ & $56 \mathrm{MHz}$ & \\
Sentech (Total) & $106 \mathrm{MHz}$ & & \\
& & & \\
\hline
\end{tabular}




\begin{tabular}{|c|c|c|c|}
\hline OPERATOR & FREQUENCY BAND & SPECTRUM ALLOCATED & USAGE \\
\hline Neotel & $850 \mathrm{MHz}$ & $22 \mathrm{MHz}$ & CDMA \\
\hline Neotel & $1800 \mathrm{MHz}$ & $22 \mathrm{MHz}$ & GSM \\
\hline NEOTEL & $2100 \mathrm{MHz}$ & $20 \mathrm{MHz}$ & UMTS \\
\hline Neotel & $3.5 \mathrm{GHz}$ & $56 \mathrm{MHz}$ & WIMAX \\
\hline NeOTEL (Total) & $120 \mathrm{MHz}$ & & \\
\hline USALS & $1800 \mathrm{MHz}$ & $22 \mathrm{MHz}$ & GSM \\
\hline USALS & $3.5 \mathrm{GHz}$ & $56 \mathrm{MHz}$ & WIMAX \\
\hline USALS & $78 \mathrm{MHz}$ & & \\
\hline VODACOM & $900 \mathrm{MHz}$ & $22 \mathrm{MHz}$ & GSM \\
\hline \multirow[t]{2}{*}{ VODACOM } & $1800 \mathrm{MHz}$ & $22 \mathrm{MHz}$ & GSM \\
\hline & & & UMTS \\
\hline VODACOM & $2000 \mathrm{MHz}$ & $5 \mathrm{MHz}$ & TDD \\
\hline VODACOM & $2100 \mathrm{MHz}$ & $20 \mathrm{MHz}$ & UMTS \\
\hline VODACOM (TOTAL) & $69 \mathrm{MHz}$ & & \\
\hline MTN & $900 \mathrm{MHz}$ & $22 \mathrm{MHz}$ & GSM \\
\hline \multirow[t]{2}{*}{ MTN } & $1800 \mathrm{MHz}$ & $22 \mathrm{MHz}$ & GSM \\
\hline & & & UMTS \\
\hline MTN & $2000 \mathrm{MHz}$ & $5 \mathrm{MHz}$ & TDD \\
\hline MTN & $2100 \mathrm{MHz}$ & $20 \mathrm{MHz}$ & UMTS \\
\hline MTN (TOTALS) & $69 \mathrm{MHz}$ & & \\
\hline Cell C & $900 \mathrm{MHz}$ & $22 \mathrm{MHz}$ & GSM \\
\hline \multirow[t]{2}{*}{ Cell C } & $1800 \mathrm{MHz}$ & $22 \mathrm{MHz}$ & GSM \\
\hline & & & UMTS \\
\hline Cell C & $2000 \mathrm{MHz}$ & $5 \mathrm{MHz}$ & TDD \\
\hline Cell $\mathrm{C}$ & $2100 \mathrm{MHz}$ & $20 \mathrm{MHz}$ & UMTS \\
\hline Cell C (Totals) & $69 \mathrm{MHz}$ & & \\
\hline WBS & $2500 \mathrm{MHz}$ & $14 \mathrm{MHz}$ & WIMAX \\
\hline WBS & $1800 \mathrm{MHz}$ & $15 \mathrm{MHz}$ & IBURST \\
\hline Cell C (Totals) & $29 \mathrm{MHz}$ & & \\
\hline
\end{tabular}


A comprehensive spectrum strategy should be developed to reconcile the interests of all the different categories of spectrum users. This strategy should balance commercial and public policy objectives without inefficient allocation of the available scarce spectrum. It is desirable that the allocation of the spectrum should be done in a transparent way to allow all the players and users in industry with the necessary information and planned allocations of ICASA. An appeal process should also be established by ICASA for all players in the industry against decisions that were taken to enable them to plan and adjust their business plans and strategies to foster growth optimally in South Africa.

\subsection{Relation to gross domestic product}

The idea that mobile phones bring economic growth is further supported according to an article in The Economist of 17 November 2007. Leonard Waverman of the London Business School has calculated that an extra ten mobile phones per 100 people in a typical developing country leads to an extra half a percentage point of growth in GDP per person. The benefits of mobile phones are very promising. According to Waferman places with bad roads, few trains and insufficient landlines, mobile phones are a good substitute for travel. It also allows price data to be distributed more quickly and enable traders to reach wider markets. It also eases the process of doing business. He has however a condition for this to materialize. For governments in such countries to realize the economic benefits of mobile phones, they need to do away with state monopolies, allow the issue of new licenses to new operators to enter the market and they must slash taxes on handsets.

The positive relation between gross domestic product and mobile phones was confirmed at a Telecoms Technology Selection for African Implementation of Social Responsibility conference held during November 2007 in Cape Town. It was stated at the conference that there are currently 167 million mobile subscribers in the 38 countries of Sub Sahara Africa. Projections are that this figure can increase to 300 million in 2011. Research revealed at this conference stated that for each $1 \%$ increase in mobile penetration, GDP per capita goes up by US $\$ 240$. Another fact revealed was for each $1 \%$ increase in internet penetration, GDP per capita goes up by US\$493. These facts clearly confirms that technology implementation in a developing country creates growth opportunities for the inhabitants of a country.

The efficient allocation of the available scarce frequencies is therefore even more a non-negotiable argument to foster development and growth in South Africa.

TD, 3(2), December 2007, pp. 351-394 


\section{Conclusion}

The available frequency spectrum is a very scarce resource of any country. It is therefore important that the regulatory body of frequencies, namely ICASA, should maximize the spectrum utilization effectively. Various options exist to allocate the available scarce spectrum. One option is the decisions of government, which will allocate the available spectrum. The easy process is to allocate the same amount of spectrum to all the registered competitors in the field. The doubt in all the players' mind with this option is on what basis the authorities will make these allocations, because there are other important factors that must also be considered than just the number of players. The second option is spectrum auctions which occur in some developed economies where the operator must maximize spectrum utilization in order to recoup their investment costs. The downside of this tactic is that the money spent to buy the service, could be better spent in delivering services in Africa and South Africa rather than recouping the increased cost of operation of the players in the market with higher prices.

There are also other methods that can be considered to allocate the available scare spectrum. Firstly, to normalise the spectrum holding based on the market penetration (proportion of subscribers within the population) for each operator. This method of allocation should remove the influence of the size of the customer base. Secondly, to divide the aggregated revenue per unit spectrum by the total population base of a country. This method of allocation compares the value created per unit spectrum per capita of a country.

The playing fields are complex due to convergence and proliferation of new technologies. New access to technologies tends to maximise spectrum efficiency in the international environment. Two principles emanate from this observation, namely regulators should not be prescriptive about what technologies may be selected by operators to serve their specific markets effectively. To restrict access to WiMAX spectrum to pre-selected operators only is the wrong avenue to take. Secondly, any grossly inefficient use of spectrum must be identified and processes must be initiated by ICASA in conjunction with market players to clear as much of the unused or "wasted" spectrum as possible for more efficient users and therefore the potential growth of South Africa. Much spectrum assigned to the military and to analogue broadcast sector perhaps can be freed up for the telecommunications sector to facilitate growth.

ICASA should manage the use of the spectrum and regularly audit the use of the spectrum in terms of the use by the different operators and the size of the market that they serve. This management and 
audit is necessary to ensure that the amount of spectrum allocated is always justified. It is unfair that any successful operator could be penalized for being successful because of bad management by the authority responsible for network allocation. Network planning and implementation for any operator becomes very expensive if the available spectrum to an operator is too restricted for the market it has to serve. The responsible authority should also harmonize the country's spectrum usage and allocation with global standards.

\section{References}

\subsection{Hard copy texts}

Anon. 2007. Impact of mobile phones in the developing world: The emerging world, South Africa and Africa in the global context. Vodafone Future Vision, 2(3).

Anon. 2007. A Bank in every Pocket? The Economist:18, 17 November.

AGHION, P. \& HOWITT, H. 1992. A model of growth through creative destruction. Econometrica, 60.

ARROW, K.J. 1962. The economic implications of learning by doing. Economic Studies, 29.

BUSINESS MONITOR INTERNATIONAL LTD. 2007. South African Telecommunications Report. Q3.

CORTRIGHT, J. 2001. New growth theory, technology and learning: a practitioners guide. Reviews of economic development literature and practice no 4, USA Economic Development Administration.

COYLE, D. 2005. Overview. Vodafone Policy Paper Series, 3.

DOMAR, E. D. 1946. Capital expansion, rate of growth and employment. Econometrica, 14(2).

DOMAR, E. D. 1958. Essays in the theory of economic growth. American Economic Review, 48(5).

DORNBUSCH, R., FISHER, S., \& STARTX, R. 2004. Macroeconomics. $9^{\text {th }}$ edition. New York: Mcgraw-Hill.

FEDERAL BANK OF DALLAS. 1998. Policy backgrounder, 147.

HARDING, T \& RATTSO, T. 2005. The barrier model of productivity

TD, 3(2), December 2007, pp. 351-394 
growth: South Africa. Working Paper Series, Norwegian University of Science and Technology.

HARROD, R.F. 1939. An essay in dynamic theory. The Economic Journal, 49(193).

HICKS, J. 1965. Capital and growth. Oxford: Clarendon.

HOWITT, P. 1992. A model of growth through creative destruction. Econometrica, 60.

KEYNES, J.M. 1936. The general theory of economics, interest and money. London: Macmillan.

KURZ, M. 1963. A two-sector extension of Swan's model of economic growth: the case of no technical change. International Economic Review, 4(1).

LEONTIEF, W. 1941. Essays in economics: theories and theorizing. New York: Oxford University Press.

MEADE, J.E. 1983. A Neo-classical theory of economic growth. Reprint of 1962 ed. Westport Cons: Greenwood.

MILL, J.S. 1848. The principles of political economy with some of their applications to social philosophy. $1^{\text {st }}$ ed. London: Longmans Green.

MOHR, P. \& FOURIE, L. 2004. Ekonomie vir Suid Afrikaanse studente. $3^{\text {rd }}$ edition. Pretoria: Van Schaik.

MOKYR,J. 2005. Long-term Economic Growth and the History of Technology in the Handbook of Economic Growth, Volume 1B. Edited by Aghion, P. \& Durlauf, S. N. Elsevier B.V.

Munn, J. 2007.

Africa: Entering the door to opportunity. Paper read at the conference of Telecoms Technology Selection for African Implementation of Social Responsibility in Cape Town. 16 November.

OSHIKOYA, T.W. \& HUSSAIN, M.N. s.a. Information technology and the challenge of economic development in Africa. African Development Bank Economic Research Papers, 36.

PHELPS, E.S. 1961. The golden rule of accumulation: a fable for Growthmen. American Economic Review, 51 Sep.

PHELPS, E.S. 1966. Models of technical progress and the golden rule of research. Review of Economic Studies, 33.

PIGOU, A.C. 1920. The economics of welfare. London: Macmillan.

RAMSEY, F.P. 1926. Truth and probability in the foundations of mathematics and other logical essays. $1^{\text {st }}$ edition. London: 
Kegan \& Trubner.

RICARDO, D. 1817. On the principles of political economy and taxation. London: John Murry.

ROBINSON, J.V. 1962. Contributions to modern economics. New York: Academic Press.

ROELLER, L.H. \& WAVERMAN, L. 2001. Telecommunications infrastructure and economic development: a simultaneous approach. American Economic Review, 91 (4).

ROMER, P.M. 1986. Increasing returns and long-run growth. Journal of Political Economy, 94 Oct.

ROMER, P.M. 1987. Growth based on increasing returns due to specialization. American Economic Review, 77.

ROMER, P.M. 1990. Endogenous technological change. Journal of Political Economy, 98(5).

SAMUEL, J., SHAH, N \& HADINGHAM, W. 2005. Mobile communications in South Africa, Tanzania and Egypt: Results from community and business surveys. Vodafone Policy Paper Series, 3.

SAMUELSON, P.A., DORFMAN, R. \& SOLOW, R.M. 1958. Linear programming and economic analysis. The American Economic Review, 48(4).

SMIT, P.C., DAMS, D.J., MOSTERT, J.W., OOSTHUIZEN, A.G., VAN DER VYVER, T.C. \& VAN GASS, W. 1997. Economics: a South African perspective. $2^{\text {nd }}$ edition. Kenwyn: Juta $\&$ Co.

SMITH, A. 1904. An inquiry into the nature and causes of the wealth of nations. $5^{\text {th }}$ edition. London: Methuen $\&$ Co.

SOLOW, R.M. 1956. A contribution to the theory of economic growth. Quarterly Journal of Economics, 70 (1).

SWAN, T. 1956. Economic growth and capital accumulation. Economic Record, 32(2).

UZAWA, H. 1965. Optimum technical change in an aggregate model of economic growth. International Economic Review, 6.

VON BOHM-BAWERK, E. 1959. Capital and interest: Volume II Positive Theory of Capital. 1959 translation. South Holland, Illinois: Libertarian Press

VON WIESER, F.1893. Natural value. Edited edition with preface by W Smart. London: Macmillan.

WALRAS, L. 1874. Elements of pure economics. London: Allen \& 
Unwin

WAVERMAN, L. 2001. Telecommunications infrastructure and economic development: a simultaneous approach. American Economic Review, 91(4).

WAVERMAN, L., MESCHI, M. \& FUSS, M. 2005. The impact of telecoms on economic growth in developing countries: Africa the impact of mobile phones. Vodafone Policy Paper Series, 3.

\subsection{Webliography}

CEPA. 2007. The history of economic thought. http:// cepa.newschool.edu/het/essays_Date of access: 11 July 2007.

ECONOMICS. 2007. Famous economists. http:// www.economics.about.com/od/famouseconomists Date of access: 14 July 2007.

ECONOMICS. 2007. Economists. http:/ / economyprofessor.com Date of access: 31 August 2007.

MONYOOE, L. s.a. Economic growth and international competitiveness. http://www.nrf.ac.za Date of access: 9 July 2007

South Africa. 2007. Accelerated growth initiative of South Africa http: / /www.info.gov.za/documents/index_Date of access: 9 July 2007.

South Africa. 2006. Annual report of accelerated growth initiative of South Africa. http://www.info.gov.za/documents/index Date of access: 9 July 2007.

USA. 2007. US Department of Commerce. www.ntia.doc.gov/ osmhome/frequen- cyallocations_Date of access: 27 July 2007. 